\title{
HUBUNGAN FAKTOR PENGETAHUAN DAN PERILAKU TERHADAP LINGKUNGAN DALAM RANGKA PENCEGAHAN DBD PADA KELUARGA SISWA DI SMA NEGERI 1 BERASTAGI KECAMATAN BERASTAGI KABUPATEN KARO TAHUN 2017
}

\author{
Susanti br Perangin-Angin* \\ Jurusan Kesehatan Lingkungan \\ Dosen Poltekkes Kemenkes Medan
}

\begin{abstract}
Infectious diseases caused by viruses from the group of Arbovirosis group A and B problematic in Indonesia are Dengue Hemorrhagic Fever (DHF). The disease is transmitted by mosquito vector bites. This disease not only often cause outbreaks but also cause adverse social and economic impact. Social losses that occur, among others, caused panic in the family, the death of family members, and diminished life expectancy of the population. In 2015, there were recorded 126,675 DHF patients in 34 provinces in Indonesia, and 1,229 of them died. The number is higher than the previous year of 100,347 people with DHF and as many as 907 patients died in 2014. This can be caused by climate change and low awareness to maintain environmental cleanliness. This research is analytic observational with cross sectional approach that aims to know the Factor of Knowledge and Environment to the action of Dengue Prevention on Family Students in SMA Negeri 1 Berastagi Sub District Berastagi Regency of Karo Year 2017, with method used in sampling is non prababiliy sampling that is sampling quota (Quota sampling) is a sampling technique based on the fulfillment of the specified samples. To determine the representativeness of the sample to the population determined sample of 300 students taken in class 11 as many as 130 students, grade 12 as many as 170 students. The results of this study indicate that the level of knowledge of respondents is generally good that is equal to $72 \%$, while the actions of respondents in the category of less that is equal to $64.3 \%$ and the environment included in the category of less that is equal to 51,7\%. Result of analysis of knowledge and environment relationship with student action about DHF in order to prevent DBD in family of student in SMA Negeri 1 Berastagi Sub District Berastagi Regency of Karo. Based on hypothesis test using chi square test known that knowledge variable do not have significant relation to environment at p.value 0,992. And analysis result of relation between student action variable about DHF has no significant relation to student environment at p.value 0,046. This research can be concluded that knowledge about DHF is good but action and environment in order to prevent DHF less. In this research, it is advisable to keep the environment cleaner in order not to become Aedes aegypti mosquito breeding media that is in the form of mosquito nest eradication $(P S N)$, fogging, abatization, $3 M$ implementation (drain, cover and bury). In every health problem including in effort of DHF, Behavioral factors always play an important role. Attention to behavioral factors is just as important as attention to environmental factors, especially in terms of disease prevention efforts.
\end{abstract}

Keywords : dbd, knowledge, environment and action

\section{PENDAHULUAN}

\section{Latar Belakang}

Penyakit Demam Berdarah Dengue (DBD) atau Dengue Haemorragic Fever (DHF) sampai saat ini merupakan salah satu masalah kesehatan masyarakat di Indonesia yang cenderung meningkat jumlah pasien serta semakin luas penyebarannya. Penyakit DBD ini ditemukan hampir di seluruh belahan dunia terutama di negara-negara tropik dan subtropik, baik sebagai penyakit endemic maupun epidemic. Hasil studi epidemiologik menunjukkan bahwa DBD menyerang kelompok umur balita sampai dengan umur sekitar 15 tahun. Kejadian Luar biasa(KLB) dengue biasanya terjadi didaerah endemic dan berkaitan dengan datangnya musim hujan, sehingga terjadi peningkatan aktivitas dengue pada musim hujan yang dapat menyebabkan terjadinya penularan penyakit DBD pada manusia melalui vector Aedes. Sehubungan dengan mortalitas dan morbiditas, DBD disebut the most mosquito transmitted disease (Djunaedi,2006).

Sebelum tahun 1970, hanya 9 negara yang mengalami wabah DBD, namun sekarang DBD menjadi penyakit endemic pada lebih dari 100 negara, diantaranya Afrika, Amerika, Mediterania Timur, Asia Tenggara dan Pasifiik Barat memiliki angka tertinggi kasus DBD. Jumlah kasus di Amerika, Asia Tenggara dan pasifik Barat telah meleawi 1,2 juta kasus di 2010. 
Pada tahun 2013 dilaporkan terdapat sebanyak 2,35 juta kasus di Amerika, dimana 37.687 kasus merupakan DBD berat (WHO,2014)

Saat ini bukan hanya terajdi peningkatan jumlah kasus DBD, tetapi penyebarannya diluar daerah tropis dan subtropics, contohnya di Eropa, transmisi local pertama kali dilaporkan di Perancis dan Kroasia pada tahun 2010. Pada tahun 2012, terjadi lebih dari 2.000 kasus DBD pada lebih dari 10 negara di Eropa. Setidaknya 500.000 penderita DBD memerlukan rawat inap setiap tahunnya, dimana proporsi penderita sebagian besar adalh anak-anak dan 2,5\% diantaranya dilaporkan meninggal dunia (WHO, 2014).

Penyakit DBD di Indonesia pertama kali ditemukan di Surabaya tahun 1968, tetapi konfirmasi virologis baru diperoleh tahun 1972. Kasus pertama di Jakarta dilaporkan tahun 1968, diikuti laporan dari Bandung (1972) dan Yogyakarta (1972).Di Indonesia terjadi peningkatan angka rata-rata kejadian DBD periode 2013-2014, tingginya kasus DBD ini menjadi sorotan Kemenkes tahun 2014. Data kemenkes menunjukkan Insiden Rate kasus DBD tahun 2012 adalah 37.11 atau setara 90.245 kasus DBD. Sedangkan 2013 naik menjadi 48,85 kasus (hingga pertengahan 2013 tercatat 48.905 kasus) yang dihitung per 100 ribu penduduk termasuk 376 orang diantaranya meninggal dunia. Jadi, pada dasarnya DBD adalah penyakit yang sangat umum di Indonesia. (Indopos,2014).

Saat ini Indonesia menduduki peringkat kedua penderita DBD setelah Brazil. Bahkan menurut data Kementrian Kesehatan tahun 2009-2011 jumlah kematian akibat DBD di Indonesia mencapai 1.125 kasus. Data tersebut sekaligus menempatkan Indonesia di Asia Tenggara sebagai negara tertinggi dalam kasus penyakit DBD.

Pada tahun 2015, tercatat terdapat sebanyak 126.675 penderita DBD di 34 provinsi di Indonesia, dan 1.229 orang diantaranya meninggal dunia. Jumlah tersebut lebih tinggi dibandingkan tahun sebelumnya yakni sebanyak 100.347 penderita DBD dan sebanyak 907 penderita meninggal dunia pada tahun 2014. Hal ini dapat disebabkan oleh perubahan iklim dan rendahnya kesadaran untuk menjaga kebersihan lingkungan.

Berdasarkan data dari Dinas Kesehatan Sumatera Utara disebutkan hingga September 2013 sebanyak 3.060 kasus DBD di Sumut. Ada 4 kabupaten yang indikatornya masih diatas standart yaitu Siantar 180/100.000 penduduk, Sibolga 170,9 /100.000 penduduk, Gunung Sitoli 79,3/100.000 penduduk dan Tebing Tinggi 60/100.000 penduduk.

Penyakit DBD telah menyebar luas ke seluruh wilayah Provinsi Sumatera Utara sebagai Kejadian Luar Biasa ( KLB ) dengan angka kesakitan dan kematian yang relatif tinggi. Berdasarkan data di wilayah Provinsi Sumatera Utara terdapat 8 daerah endemis DBD, yaitu : Kota Medan, Kabupaten Deli Serdang, Kota Binjai, Kabupaten Langkat, Kabupaten Asahan, Kota Tebing Tinggi, Kota Pematang Siantar dan Kabupaten Karo. Angka kejadian DBD di Propinsi
Sumatera Utara dalam lima tahun terakhir terus meningkat, tahun 2005 terjadi 3.790 kasus dengan kematian 68 orang,tahun 2006 terjadi 2.222 kasus dengan kematian 34 orang, tahun 2007 terjadi 4.427 kasus dengan kematian 41 orang, tahun 2008 terjadi 4.401 kasus dengan kematian50 orang dan tahun 2009 terjadi 4.705 kasus dengan kematian 58 orang (Dinkes Provinsi Sumut, 2010)

Berdasarkan data survey jentik oleh mahasiswa Poltekkes Kemenkes Medan Jurusan Kesehatan Lingkungan Kabanjahe tahun 2014, yang dilakukan di Kabanjahe, didapatkan data : Angka bebas jentik sebanyak $41,1 \%$, House Indeks sebanyak 58,8\%, Containert Indeks sebanyak 50,2 \%, Breteau Indeks sebanyak 176,5\% dan Density Figure sebanyak >7(angka density figure( DF.5 risiko tinggi) dan Density Figure yang didapatkan yaitu $>5$, maka sangat memungkinkan perkembangbiakan nyamuk Aedes aegypti akan semakin meningkat dan penyebaran penyakit demam berdarah akan semakin meningkat. DF adalah kepadatan jentik Aedes aegypti yang merupakan gabungan dari $\mathrm{HI}, \mathrm{CI}$ dan $\mathrm{BI}$.

Menurut Ghotar (2012) saat ini larva sudah mengalami perubahan karena sudah mampu berkembang di air yang langsung menyentuh tanah, dan jentik nyamuk Aedes aegypti sudah dapat hidup kotor.

Didalam perundang-undangan pemerintah merasa perlu usaha pemberantasan penyakit menular,hal ini di atur dalam undang-undang RI No.36 tahun 2009 pasal 152 ayat 1 yang berbunyi bahwa pemerintah,pemerintah daerah dan masyarakat bertanggung jawab melakukan upaya pencegahan,pengendalian,dan pemberantasan penyakit menular serta akibat yang di timbulkannya.(Undangundang RI, 2009)

Dilihat dari penularan penyakit DBD salah satunya juga disebabkan oleh mobilisasi penduduk, sehingga kemungkinan terjangkit pada masyarakat Kabupaten Karo. Kasus DBD di Kabupaten Karo pertama sekali ditemukan pada tahun 1997 pada seorang anak sekolah dasar (SD) di Kota Kabanjahe. Dari hasil survey sementara bahwa penularan DBD dikarenakan banyaknya sampah-sampah seperti: batok kelapa,kaleng-kaleng bekas, dan drum penampungan air hujan, yang memungkinkan menjadi tempat bersarangnya nyamuk Aedes aegypti.

Berdasarkan laporan tahunan penyakit program DBD Kabupaten Karo tahun 2013 terdapat 82 kasus dengan kasus tertinggi berada di puskesmas Kabanjahe dengan 43 kasus, Dolat Rakyat 7 kasus, Barus Jahe 2 kasus, Tiga Panah 3 kasus, desa Singa 7 kasus, desa Naman 8 kasus, Kuta Buluh 4 kasus, Munthe 7 kasus, dan kasus terendah berada di desa Tiga Binanga yaitu hanya dengan 1 kasus saja. (Puskesmas Kabanjahe, 2013).

Berdasarkan Laporan Terakhir dari Dinas Kesehatan Tahun 2016 bahwa DBD masuk 10 jenis penyakit yang terbesar yang menempati urutan ke 8 yaitu sebanyak 207 penderita dan ada setelah TBC dan Malaria dengan Insiden rate 0,6 dan beberapa diantara penderita DBD ada yang meninggal ( Profil Dinas Kesehatan Tahun 2016).

Upaya pencegahan penyebaran penyakit DBD, membutuhkan peranan keluarga dalam melaksanakan Pemberantasan Sarang nyamuk Demam Berdarah Dengue 
(PSN DBD) agar setiap rumah bebas dari jentik nyamuk Aedes aegypty (Depkes RI, 1998).

Masalah perilaku manusia ada yang menguntungan (positif) dan ada yang merugikan (negatif). Jika dihubungkan dengan pemberantasan sarang nyamuk demam berdarah dengue perilaku positif seperti melakukan upaya menguras, menutup, mengubur (3M) sedangkan perilaku yang negatif merupakan kontradiksi dari upaya ini.

Selain kegiatan pemberantasan sarang nyamuk, upaya lain dalam pengendalian vektor untuk mencegah kejadian DBD dilakukan dengan menghindari kontak dengan nyamuk dewasa. Pencegahan ini dapat dilakukan dengan memperhatikan faktor kebiasaan keluarga diantaranya kebiasaan tidur siang, penggunaan kelambu siang hari, pemakaian anti nyamuk siang hari,dan kebiasaan menggantung pakaian bekas yang dapat diubah atau disesuaikan untuk mengurangi kemungkinan terjadinya kasus DBD terhadap salah satu anggota keluarga.

Perilaku masyarakat dalam pemberantasan sarang nyamuk demam berdarah dengue di Kecamatan Berastagi belum terwujud secara optimal, oleh karena masih ditemukan sampah-sampah yang dibuang sembarangan/berserakan di halaman rumah dan di lingkungan pemukiman seperti: kaleng-kaleng bekas, banban bekas, tempurung, serta masih ditemukannya tempattempat perindukan dan perkembangbiakan nyamuk demam berdarah dengue di dalam dan di luar rumah, yang kesemuanya ini dapat merupakan faktor penyebab masih tingginya kasus penyakit demam berdarah dengue.Berdasarkan latar belakang di atas maka penulis melakukan penelitian tentang " hubungan faktor Pengetahuan dan perilaku terhadap lingkungan dalam rangka pencegahan DBD pada keluarga siswa di SMA Negeri 1 Berastagi Kecamatan Berastagi Kabupaten Karo Tahun 2017 “

\section{Permasalahan}

Berdasarkan uraian pada latar belakang, maka rumusan masalah dalam penelitian ini adalah : Bagaimana hubungan antara faktor pengetahuan dan perilaku terhadap lingkungan dalam rangka pencegahan DBD pada keluarga siswa di SMA Negeri 1 Berastagi Kecamatan Berastagi Kabupaten Karo Tahun 2017 ?

\section{METODE PENELITIAN}

\section{Jenis Penelitian}

Penelitian ini merupakan penelitian observasional analitik dengan pendekatan cross sectional yang bertujuan untuk mengetahui faktor pengetahuan dan perilaku terhadap lingkungan dalam rangka pencegahan DBD pada keluarga siswa di SMA Negeri 1 Berastagi Kecamatan Berastagi Kabupaten Karo Tahun 2017

\section{Lokasi dan Waktu Penelitian}

Penelitian ini dilaksanakan di SMA Negeri 1 Berastagi Kecamatan Berastagi Kabupaten Karo yang beralamat di Jln.Jamin Ginting No.12 Telp//Fax. 0628-
91075 Berastagi dengan pertimbangan bahwa jumlah siswa pada sekolah tersebut cukup banyak, lokasi terletak di lintas Kabupaten sehingga memungkinkan daerah tersebut menjadi tempat persinggahan yang dapat memberikan pangaruh positif dan negative bagi masyarakat terutama siswa. Penelitian ini dilaksanakan dari bulan Juli sampai Oktober 2017

\section{Populasi dan sampel}

Populasi penelitian ini adalah Siswa SMA Negeri 1 Berastagi Kecamatan Berastagi Kabupaten Karo Semester Ganjil Tahun 2017 yang berjumlah 1171 siswa dimana kelas 10 terdiri X MIPA 1 sampai X MIPA 6 sebanyak 212 orang sedangkan X IPS $1-$ X IPS 4 sebanyak 142 orang, kelas 11 terdiri dari XI MIPA 1 sampai XI MIPA 8 sebanyak 256 orang dan XI IPS 1 sampai XI IPS 5 sebanyak 162 orang dan terakhir kelas XII MIPA 1 sampai XII MIPA 12 sebanyak 278 orang dan XII IPS 1 sampai XII IPS 4 sebanyak 121 orang.

1. Kriteria Inklusi

a. Sampel merupakan siswa terpilih yang hadir pada saat pengambilan data

b. Terdaftar sebagai siswa yang aktif di SMA Negeri 1 Berastagi Kecamatan Berastagi Kabupaten Karo pada periode penelitian

\section{Kriteria Eksklusi}

a. Tidak bersedia diwawancarai

Tidak hadir pada saat pengambilan data.

Metode sampling yang digunakan dalam penelitian adalah non prababiliy sampling yaitu sampling quota ( Quota sampling ) yaitu teknik pengambilan sampel yang didasarkan pada terpenuhinya sampel yang ditentukan. Untuk penetapan keterwakilan sampel terhadap populasi ditentukan sampel sebesar 300 siswa yang diambil dikelas 11 sebanyak 130 orang siswa, kelas 12 sebanyak 170 orang siswa dimana rumus yang dipakai adalah :

$$
n=\frac{N}{N \cdot d^{2}+1}
$$

Dimana $: \mathrm{n}=$ Jumlah Sampel

$\mathrm{N}=$ Jumlah Populasi

$\mathrm{d}^{2}=$ Presisi yang diinginkan ( $5 \%$ atau $\left.10 \%\right)$

$\mathrm{n}=$ 1171

$$
\text { 1171. }(0,05 \%)^{2}+1
$$

$\mathrm{n}=1171 / 3,9=300,2=300$ siswa

\section{Pengumpulan Data}

Metode pengumpulan data dalam penelitian ini adalah wawancara menggunakan kuesioner yang terdiri dari beberapa pertanyaan seperti : karakteristik responden, pengetahuan mengenai DBD dan perilaku serta lingkungan dalam pencegahan DBD. Untuk mempermudah kegiatan ini maka siswa yang terpilih sebagai sampel dikumpulkan dalam satu ruangan (kelas/aula). Setiap siawa mendapat 1 eks kuesioner yang akan diisi, selanjutnya peneliti memberikan penjelasan terlebih dahulu mengenai cara 
pengisian kuesioner serta memberikan penjelasan, jika ada kata atau kalimat yang kurang dipahami oleh siswa serta peneliti mengamati lingkungan siswa ke rumah siswa yang dipilih sebagai sampel.

\section{Aspek Pengukuran}

Penentuan kategori variabel penelitian dilakukan menggunakan aspek pengukuran sebagai berikut :

1. Pengetahuan diukur dengan memberikan 12 pertanyaan pada responden, setiap jawaban yang salah diberi kode 0 dan 1 untuk jawaban yang benar, selanjutnya ditentukan katagori berikut :
a. Baik, jika total skore yang diperoleh responden $11-12$ point
b. Sedang, jika total skore yang diperoleh responden 10 point
c. Kurang, jika total skore yang diperoleh responden 1-9 point

2. Perilaku diukur dengan memberikan 16 pertanyaan pada responden, setiap jawaban yang salah diberi kode 0 dan 1 untuk jawaban yang benar, selanjutnya ditentukan katagori berikut :
a. Baik, jika total skore yang diperoleh responden $10-16$ point
b. Kurang, jika total skore yang diperoleh responden 1 - 9 point

3. Lingkungan diukur dengan memberikan 4 pertanyaan pada responden, setiap jawaban yang salah diberi kode 0 dan 1 untuk jawaban yang benar, selanjutnya ditentukan katagori berikut :
a. Baik, jika total skore yang diperoleh responden 3 - 4 point
b. Kurang, jika total skore yang diperoleh responden 1 - 2 point

\section{Analisa Data}

Data yang telah dikumpulkan diolah dengan bantuan computer dan disajikan dalam bentuk tabulasi, grafik dan narasi. Uji Statistik yang digunakan untuk pengujian hipotesis adalah chi square dengan tingkat kepercayaan $95 \%$ (Tingkat kemaknaan 5\%)

\section{Hasil}

\section{Karakteristik Responden}

Gambaran karakteristik subyek penelitian sebagai hasil analisis dapat dilihat pada tabel 5.1 berikut :

Tabel 5.1. Distribusi Frekwensi Menurut Karakteristik Responden di SMA Negeri 1 Berastagi Kecamatan Berastagi Kabupaten Karo Tahun 2017

\begin{tabular}{lcc}
\hline Jenis Kelamin & Frekwensi & $\begin{array}{c}\text { Persentase } \\
(\%)\end{array}$ \\
\hline Laki-laki & 107 & 35,7 \\
\hline Perempuan & 193 & 64,3 \\
\hline Total & 300 & 100 \\
\hline Umur Siswa & & \\
\hline
\end{tabular}

\begin{tabular}{lcc}
\hline $15-17$ thn & 207 & 69 \\
\hline $18-19$ thn & 93 & 31 \\
\hline Total & 300 & 100 \\
\hline Kelas & & \\
\hline XI & 130 & 43,3 \\
\hline XII & 170 & 56,7 \\
\hline Total & 300 & 100 \\
\hline Suku & & \\
\hline Karo & 211 & 70,3 \\
\hline Selain Karo & 89 & 29,7 \\
\hline Total & 300 & 100 \\
\hline Jumlah & & \\
Penghuni & & 56 \\
\hline 1-5 orang & 168 & 44 \\
\hline 6-10 orang & 132 & 100 \\
\hline Total & 300 &
\end{tabular}

Tabel 5.1 menunjukkan bahwa responden yang paling dominan adalah perempuan sebanyak 64,3\% sedangkan laki-laki sebanyak 35,7\%. Rentang umur responden dominan berada pada interval $14-17$ tahun sebanyak 69\% dan pada umur 18-19 tahun sebanyak 31\%. Kelas yang terbanyak responden adalah kelas XII sebanyak 56,7\% dan kelas XI sebanyak 43,3\%. Suku yang paling dominan pada responden adalah suku karo sebanyak 70,3\% sedangkan suku lain yaitu suku Jawa,Batak Toba sebanyak 29,\% dan yang terakhir adalah jumlah penghuni dalam satu rumah yang paling banyak 1-5 orang sebanyak $56 \%$ sedangkan jumlah penghuni dalam satu rumah yaitu 6-10 orang sebanyak 44 orang.

\section{Pengetahuan Siswa Tentang Demam Berdarah Dengue}

Variabel pengetahuan memiliki 12 sub variabel. Dengan melalui coding, dapat diketahui total nilai pengetahuan.. Tingkat pengetahuan siswa dapat dilihat pada tabel 5.2.

Tabel 5.2. Distribusi Frekwensi Responden Menurut Tingkat Pengetahuan di SMA Negeri 1 Berastagi Kecamatan Berastagi Kabupaten Karo Tahun 2017

\begin{tabular}{lcc}
\hline $\begin{array}{l}\text { Tingkat } \\
\text { Pengetahuan }\end{array}$ & Frekwensi & Persentase (\%) \\
\hline Baik & 216 & 72 \\
\hline Sedang & 76 & 25,3 \\
\hline Kurang & 8 & 2,7 \\
\hline Total & 300 & 100 \\
\hline
\end{tabular}

Tabel 5.2. menunjukkan bahwa tingkat pengetahuan siswa mengenai DBD mayoritas pada kategori baik sebesar $72 \%$, sedangkan responden dengan pengetahuan sedang sebanyak 25,3\% dan pengetahuan kurang sebanyak 2,7\% Hal ini membuktikan bahwa sebenarnya masih banyak siswa SMA yang belum memahami hal-hal yang berkaitan dengan DBD, sehingga berpotensi ada penderita DBD

Berdasarkan hasil wawancara diketahui bahwa 99,7\% responden menyatakan pernah mendengar tentang DBD, pengetahuan penyebab DBD sebanyak $52 \%$, 
pengetahuan gejala DBD sebanyak 97,3\%, pengetahuan binatang penular DBD sebanyak 96,3\%, pengetahuan dimana binatang penular berkembang biak sebanyak $98,7 \%$, pengetahuan cara mencegah DBD 98\%, pengetahuan pencegahan $3 \mathrm{M}$ plus sebanyak $80 \%$, pengetahuan pelaksanaan PSN, pengetahuan pertolongan terhadap anggota keluarga yang menderita DBD sebanyak $98,3 \%$, pengetahuan upaya melindungi diri dari gigitan nyamuk sebanyak 97,7\%, pengetahuan dalam memberantas nyamuk sebanyak $94,3 \%$ dan pengetahuan dalam 1 bulan terkhir menguras bak sebanyak 84\%. Hasil jawaban dari pertanyaan pengetahuan dapat dilihat pada tabel 5.3.

Tabel 5.3. Distribusi Frekwensi Responden Menurut Jawaban dari Pertanyaan Tentang Pengetahuan di SMA Negeri 1 Berastagi Kecamatan Berastagi Tahun 2017

\begin{tabular}{|c|c|c|c|c|c|}
\hline \multirow{2}{*}{ No } & \multirow{2}{*}{ Pertanyaan } & \multicolumn{2}{|c|}{ Benar } & \multicolumn{2}{|c|}{ Salah } \\
\hline & & $\mathrm{N}$ & $\%$ & $\mathrm{~N}$ & $\%$ \\
\hline 1 & $\begin{array}{l}\text { Pengetahuan } \\
\text { Mendengar } \\
\text { Tentang DBD }\end{array}$ & 299 & 99,7 & 1 & 0,3 \\
\hline 2 & $\begin{array}{l}\text { Pengetahuan } \\
\text { Penyebab DBD }\end{array}$ & 156 & 52 & 144 & 48 \\
\hline 3 & $\begin{array}{l}\text { Pengetahuan } \\
\text { Gejala DBD } \\
\end{array}$ & 292 & 97,3 & 8 & 2,7 \\
\hline 4 & $\begin{array}{l}\text { Pengetahuan } \\
\text { Binatang Penular } \\
\text { DBD }\end{array}$ & 289 & 96,3 & 11 & 3,7 \\
\hline 5 & $\begin{array}{l}\text { Pengetahuan } \\
\text { Dimana Binatang } \\
\text { Penular } \\
\text { Berkembang biak }\end{array}$ & 296 & 98,7 & 4 & 1,3 \\
\hline 6 & $\begin{array}{l}\text { Pengetahuan Cara } \\
\text { Mencegah DBD }\end{array}$ & 294 & 98 & 6 & 2 \\
\hline 7 & $\begin{array}{l}\text { Pengetahuan } \\
\text { Pencegahan } 3 \mathrm{M} \\
\text { Plus }\end{array}$ & 240 & 80 & 60 & 20 \\
\hline 8 & $\begin{array}{l}\text { Pengetahuan } \\
\text { Pelaksanaan PSN } \\
\end{array}$ & 269 & 89,7 & 31 & 10,3 \\
\hline 9 & $\begin{array}{l}\text { Pengetahuan } \\
\text { Pertolongan } \\
\text { Terhadap } \\
\text { Anggota Keluarga } \\
\text { Yang Menderita } \\
\text { DBD }\end{array}$ & 295 & 98,3 & 5 & 1,7 \\
\hline 10 & $\begin{array}{l}\text { Pengetahuan } \\
\text { Upaya } \\
\text { melindungi Diri } \\
\text { Dari Gigitan } \\
\text { Nyamuk }\end{array}$ & 293 & 97,7 & 7 & 2,3 \\
\hline 11 & $\begin{array}{l}\text { Pengetahuan } \\
\text { Dalam } \\
\text { memberantas } \\
\text { Nyamuk } \\
\end{array}$ & 283 & 94,3 & 17 & 5,7 \\
\hline 12 & $\begin{array}{l}\text { Pengetahuan } \\
\text { Dalam 1 Bulan } \\
\text { Terakhir } \\
\text { Menguras Bak }\end{array}$ & 252 & 84 & 48 & 16 \\
\hline
\end{tabular}

Tabel 5.3 menunjukkan bahwa masih banyak siswa secara keseluruhan dapat disimpulkan bahwa tingkat pengetahuan siswa tentang DBD belum memuaskan pada penyebab DBD dimana sebanyak 144 orang (48\%) tidak tahu penyebab DBD dan dan sebanyak 60 orang $(20 \%)$ tidak mengetahui cara pencegahan DBD $3 \mathrm{M}+$ plus penggunaannya sehingga dalam hal ini masih jauh dari yang diharapkan. Kondisi ini dapat memicu pengetahuan siswa yang kurang tepat terutama dalam pencegahan penyebab DBD dan DBD $3 \mathrm{M}+$ plus.

\section{Perilaku Siswa Tentang DBD}

Terdapat enam belas sub varibel Perilaku yaitu Perilaku habis memakai pakaian langsung dicuci, Perilaku Kebiasaan Tidak Menggantung pakaian di rumah, Perilaku Menutup Tempat Penampungan air, Perilaku Mengubur Barang-Barang Bekas, Perilaku Mengganti Air di Vas Bunga, Tempat minum air, Perilaku Memeriksa Jentik Nyamuk, Perilaku Menguras Bak Mandi/WC, Perilaku Menguras bak Mandi 1-2 kali seminggu, Perilaku Tidak hanya mengganti air di bak,

Perilaku Menggunakan Kelambu, Perilaku Menggunakan lotion setiap hari, Perilaku menggunakan obat semprot di rumah, Perilaku memeriksa Tempat Penampungan Air didalam dan diluar rumah, Perilaku setiap hari memeriksa TPA, Perilaku berada di rumah selama 10 jam, Perilaku berada di rumah sore hari. Gambaran tindakan terhadap pencegahan DBD dapat dilihat pada tabel 4.4.

Tabel 5.4 Distribusi Frekwensi Responden Menurut Tentang Perilaku Siswa di SMA Negeri 1 Berastagi Kecamatan Berastagi Kabupaten Karo Tahun 2017

\begin{tabular}{lcc}
\hline $\begin{array}{l}\text { Perilaku } \\
\text { Siswa }\end{array}$ & Frekwensi & $\begin{array}{c}\text { Persentase } \\
(\mathbf{\%})\end{array}$ \\
\hline Baik & 107 & 35,7 \\
\hline Kurang & 193 & 64,3 \\
\hline Total & 300 & 100 \\
\hline
\end{tabular}

Berdasarkan hasil pengolahan data diketahui bahwa sebagian besar siswa mempunyai tindakan yang kurang baik terhadap pencegahan DBD yaitu sebanyak 193 orang ( 64,3\% ) dan yang lainnnya tindakan baik sebesar 107 orang $(35,7 \%)$. Hasil jawaban dari pertanyaan tindakan dapat dilihat pada tabel 5.5 yaitu :

Tabel 5.5 Distribusi Frekwensi Responden Menurut Jawaban Dari Pertanyaan Tentang Perilaku Siswa Tentang DBD di SMA Negeri 1 Berastagi Kecamatan Berastagi Kabupaten Karo Tahun 2017

\begin{tabular}{|c|c|c|c|c|c|}
\hline \multirow{2}{*}{ No } & \multirow{2}{*}{ Pertanyaan } & \multicolumn{2}{|c|}{ Ya } & \multicolumn{2}{|c|}{ Tidak } \\
\hline & & $\mathrm{N}$ & $\%$ & $\mathrm{~N}$ & $\%$ \\
\hline 1 & $\begin{array}{l}\text { Perilaku habis } \\
\text { memakai pakaian } \\
\text { langsung dicuci }\end{array}$ & 138 & 46 & 162 & 54 \\
\hline 2 & $\begin{array}{l}\text { Perilaku Kebiasaan } \\
\text { Menggantung pakaian } \\
\text { di rumah }\end{array}$ & 267 & 89 & 33 & 11 \\
\hline 3 & $\begin{array}{l}\text { Perilaku Menutup } \\
\text { Tempat Penampungan } \\
\text { air }\end{array}$ & 201 & 67 & 99 & 23 \\
\hline 4 & $\begin{array}{l}\text { Perilaku Mengubur } \\
\text { Barang-Barang Bekas }\end{array}$ & 116 & 38,7 & 184 & 61,3 \\
\hline
\end{tabular}




\begin{tabular}{|c|c|c|c|c|c|}
\hline 5 & $\begin{array}{l}\text { Perilaku Mengganti } \\
\text { Air di Vas Bunga, } \\
\text { Tempat minum air }\end{array}$ & 197 & 65,7 & 102 & 34 \\
\hline 6 & $\begin{array}{l}\text { Perilaku Memeriksa } \\
\text { Jentik Nyamuk }\end{array}$ & 177 & 59 & 123 & 41 \\
\hline 7 & $\begin{array}{l}\text { Perilaku Menguras } \\
\text { Bak Mandi/WC }\end{array}$ & 274 & 91,3 & 26 & 8,7 \\
\hline 8 & $\begin{array}{l}\text { Perilaku Menguras } \\
\text { bak Mandi } 1-2 \text { kali } \\
\text { seminggu }\end{array}$ & 234 & 78 & 66 & 22 \\
\hline 9 & $\begin{array}{l}\text { Perilaku hanya } \\
\text { mengganti air di bak }\end{array}$ & 205 & 68,3 & 95 & 31,7 \\
\hline 10 & $\begin{array}{l}\text { Perilaku } \\
\text { Menggunakan } \\
\text { Kelambu }\end{array}$ & 77 & 25,7 & 223 & 74,3 \\
\hline 11 & $\begin{array}{l}\text { Perilaku } \\
\text { Menggunakan lotion } \\
\text { setiap hari }\end{array}$ & 83 & 27,7 & 217 & 72,3 \\
\hline 12 & $\begin{array}{l}\text { Perilaku } \\
\text { menggunakan obat } \\
\text { semprot di rumah }\end{array}$ & 151 & 50,3 & 149 & 49,7 \\
\hline 13 & $\begin{array}{l}\text { Perilaku memeriksa } \\
\text { Tempat Penampungan } \\
\text { Air didalam dan diluar } \\
\text { rumah }\end{array}$ & 183 & 61 & 117 & 39 \\
\hline 14 & $\begin{array}{lrl}\text { Perilaku setiap hari } \\
\text { memeriksa TPA }\end{array}$ & 103 & 34,3 & 197 & 65,7 \\
\hline 15 & $\begin{array}{l}\text { Perilaku berada di } \\
\text { rumah ada } 10 \text { jam }\end{array}$ & 245 & 81,7 & 55 & 18,3 \\
\hline 16 & $\begin{array}{l}\text { Perilaku sore hari di } \\
\text { rumah }\end{array}$ & 241 & 80,3 & 59 & 19,7 \\
\hline
\end{tabular}

\section{Lingkungan Siswa}

Lingkungan siswa pada variabel ini ada 4 pertanyaan yaitu Jumlah Penghuni Rumah (Keadaan Rumah) yiatu melihat penghuni rumah tersebut padat atau tidak padat penghuni, Kondisi Ventilasi dimana ventilasi seluruhnya dalam keadaan baik, sebagian dalam berlubang atau hanya sebagian mempunyai ventilasi, Keadaan Jentik dalam Rumah dimana dilihat jentik di bak mandi,tempayan,ember,vas bunga, air kaki meja dan TPA AC/kuklas, Keadaan Jentik Luar Rumah yaitu melihat keberadaan jentik pada kaleng bekas, ban bekas, pagar bamboo, kolam, tempat minum burung dan drum/tong. Uraian lingkungan siswa dapat dilihat pada tabel 5.6.

Tabel 5.6. Distribusi Frekwensi Responden Menurut Lingkungan Siswa 1 Berastagi Kecamatan Berastagi Kabupaten Karo Tahun 2017

\begin{tabular}{lcc}
\hline Lingkungan & Frekuensi & Persentase (\%) \\
\hline Baik & 145 & 48,3 \\
\hline Kurang & 155 & 51,7 \\
\hline Total & $\mathbf{3 0 0}$ & $\mathbf{1 0 0}$ \\
\hline
\end{tabular}

Hasil analisis menunjukkan bahwa 51,7\% siswa mempunyai lingkungan yang kurang baik dalam rangka pencegahan DBD pada keluarga siswa SMA Negeri 1 Berastagi Kecamatan Berastagi Kabupaten karo dan siswa yang lainnya mempunyai lingkungan yang baik sebesar 48,3\%. Tabel 5.7 berikut menunjukkan distribusi jawaban responden mengenai lingkungan siswa.
Tabel 5.7 Distribusi Frekwensi esponden Menurut Jawaban Tentang Pertanyaan Lingkungan Siswa di SMA Negeri 1 Berastagi Kecamatan Berastagi Kabupaten Kar Tahun 2017

\begin{tabular}{llcccc}
\hline \multirow{2}{*}{ No } & \multirow{2}{*}{ Pertanyaan } & \multicolumn{2}{c}{ Ya } & \multicolumn{2}{c}{ Tidak } \\
\cline { 2 - 6 } & $\mathrm{N}$ & $\%$ & $\mathrm{~N}$ & $\%$ \\
\hline 1 & $\begin{array}{l}\text { Kepadatan } \\
\text { Penghuni }\end{array}$ & 113 & 37,7 & 187 & 62,3 \\
\hline 2 & $\begin{array}{l}\text { Kondisi Ventilasi } \\
\text { Rumah Baik }\end{array}$ & 177 & 59 & 123 & 41 \\
\hline 3 & $\begin{array}{l}\text { Adanya Jentik } \\
\text { dalam Rumah }\end{array}$ & 203 & 67,7 & 97 & 32,3 \\
\hline 4 & $\begin{array}{l}\text { Adanya Jentik } \\
\text { Luar Rumah }\end{array}$ & 172 & 57,3 & 128 & 42,7 \\
\hline
\end{tabular}

\subsection{Analisis Hubungan Pengetahuan, Perilaku Siswa dengan Lingkungan Siswa Tentang DBD}

Variabel yang terdiri dari faktor pengetahuan, perilaku siswa dan lingkungan dalam rangka pencegahan DBD pada keluarga siswa di SMA Negeri 1 Berastagi Kabupaten Karo Tahun 2017 dianalisis seperti pada tabel dibawah ini

Tabel 5.8. Analisis Hubungan Pengetahuan, Perilaku dengan Lingkungan Siswa Tentang DBD pada Keluarga Siswa di SMA Negeri 1 Berastagi Kabupaten Karo Tahun 2017

\begin{tabular}{|l|c|c|c|c|l|l|}
\hline \multirow{2}{*}{$\begin{array}{l}\text { Variabel } \\
\text { Independent }\end{array}$} & \multicolumn{4}{|c|}{ Lingkungan } & \multirow{2}{*}{$\mathbf{X}^{2}$} & \multirow{2}{*}{$\begin{array}{c}p- \\
\text { value }\end{array}$} \\
\cline { 2 - 5 } & $\mathbf{2}$ & $\mathbf{\%}$ & $\mathbf{N}$ & $\mathbf{\%}$ & & \\
\hline Pengetahuan & & & & & & \\
Baik & 104 & 71,7 & 112 & 72,2 & & \\
Sedang & 37 & 25,5 & 39 & 25,2 & 0,016 & 0,992 \\
Kurang & 4 & 2,8 & 4 & 2,6 & & \\
\hline Total & $\mathbf{1 4 5}$ & $\mathbf{1 0 0}$ & $\mathbf{1 5 5}$ & $\mathbf{1 0 0}$ & & \\
\hline Perilaku Siswa & & & & & & \\
Tentang DBD & & & & & & \\
$\quad \begin{array}{l}\text { Baik } \\
\text { Kurang }\end{array}$ & 60 & 41,4 & 47 & 30,3 & 3,991 & 0,046 \\
\hline Total & 85 & 58,6 & 108 & 69,7 & & \\
\hline
\end{tabular}

Tabel 5.8 menunjukkan hasil analisis hubungan pengetahuan dan lingkungan dengan perilaku siswa tentang DBD dalam rangka pencegahan DBD pada keluarga siswa di SMA Negeri 1 Berastagi Kecamatan Berastagi Kabupaten Karo. Berdasarkan uji hipotesi menggunakan uji chi square diketahui bahwa variabel pengetahuan tidak mempunyai hubungan yang bermakna terhadap lingkungan pada p.value 0,992 .

Dari hasil analisis hubungan antara variabel perilaku siswa tentang DBD mempunyai hubungan bermakna terhadap lingkungan siswa pada p.value 0,046.

\section{B. PEMBAHASAN}

Penelitian yang dilaksanakan terhadap 300 responden ditemukan responden yang dominan adalah berjenis kelamin perempuan sebanyak 193 orang $(63,4 \%)$ dan laki-laki berjumlah 107 orang $(35,7 \%)$, umur responden yang paling banyak berada pada umur kisaran 
15-17 tahun sebanyak 207 orang (69 \%) dan umur 18-19 tahun sebanyak 93 orang $(31 \%)$. Responden kelas yang diambil adalah kelas XI dan XII dan yang paling dominan adalah kelas XII sebanyak 170 orang $(56,7 \%)$. Suku yang paling dominan adalah suku karo sebanyak $70,3 \%$ dan jumlah penghuni yang paling dominan adalah 1-5 orang sebanyak 168 orang (56\%) dan jumlah penghuni lebih atau sama dengan 5 orang sebanyak 132 orang (44\%).

Pengetahuan adalah keseluruhan pemikiran, gagasan, ide,konsep dan pemahaman yang dimiliki manusia tentang dunia dan isinya termasuk manusia dan kehidupannya (Keraf,2001).sedangkan menurut Tafsir (2004) pengetahuan adalah segala sesuatu yang diketahui. Manusia memilikin rasa ingin tahu, lalu mencari, hasilnya ia tahu sesuatu. Sesuatu itulah yang dinamakan pengetahuan.

Pengetahuan responden mengenai DBD dan vector penyebabnya serta factor yang mempengaruhi keberadaan larva nyamuk Aedes aegypti sangat diperlukan untuk mencegah terjadinya penularan penyakit DBD serta menekan perkembangan dan pertumbuhan larva nyamuk Aedes aegypti (Ririh, 2005).

Pengetahuan berpengaruh sebagai motivasi awal bagi seseorang dalam berperilaku (Green,1980) seseorang yang mempunyai pengetahuan yang baik mengenai sesuatu penyakit, dalam hal ini DBD maka akan muncul sikap dan tindakan/perilaku yang benar. Jika pengetahuan seseorang semakin tinggi semakin benar pula sikap dan tindakan seseorang (Notoadmojdo,2003).

Berdasarkan hasil penelitian pada variabel pengetahuan yang dilaksanakan di SMA Negeri 1 Berastagi bahwa pengetahuan yang paling dominan adalah pengetahuan baik sebanyak 216 orang $(72 \%)$ sedang ada 76 orang $(25,3 \%)$ sedangkan pendidikan kurang sebanyak 8 orang $(2,7 \%)$. Namun pengetahuan responden tentang pencegahan DBD pada umumnya sudah baik $72 \%$, hal dapat disebabkan oleh beberapa hal antara lain pernah atau tidaknya seseorang mendapatkan penyuluhan tentang pencegahan DBD dimana responden mendapatkan informasi tentang pencegahan DBD. Informasi akan lebih lengkap dan utuh jika dibandingkan dengan informasi dari sumber non formal . Kondisi ini menunjukkan kepada kita bahwa pengetahuan amat penting peranannyadalam proses perubahan sikap dan perilaku, dari perilaku yang tidak sehat kepada perilaku yang menguntungkan bagi kesehatan.Pengetahuan responden tentang cara penularan penyakit DBD adalah melalui nyamuk Aedes aegypti namun responden belum mengathui virus Dengue sebagai penyebab terjadinya penyakit DBD sebanyak $48 \%$. DBD. Pengetahuan responden tentang cara pemberantasan Demam Berdarah tentang cara $3 \mathrm{M}$ Plus baik tetapi masih ada $20 \%$ tidak mengetahui pencegahan DBD dengan $3 \mathrm{M}$ Plus.Penelitian ini tentang pengetahuan responden terhadap pencegahan DBD sebagian besar adalah baik, namun peranan tokoh formal seperti petugas kesehatan dan nonformal seperti kader kesehatan serta informasi dari media massa sangatlah diperlukan dalam memberikan anjuran dan informasi tentang Pencegahan DBD Depkes RI, 2001).
Hasil penelitian yang dilakukan oleh Sungkar dkk pada tahun 2010 menunjukkan bahwa sebelum penyuluhan warga memiliki pengetahuan kurang berkurang setelah dilakukan penyuluhan menjadi 50,9\% dari $64,2 \%$. Sedangkan pengetahuan yang baik meningkat $1,9 \%$.

Seperti yang terjadi dengan penelitian tentang pengetahuan siswa Sekolah Dasar yang ada Di Depok tentang cara mengendalikan vektor DBD bahwa sebanyak $72,6 \%$ pengetahuan murid tentang cara mengendalikan vektor adalah dengan memberantas sarang nyamuk di tambah dengan 3M (Menutup, Menguras dan Mengubur).

Penelitian lainnya yang menggali tentang pengetahuan dimana Informan yang dipilih sesuai dengan kriteria yang ditetapkan di awal penelitian, yaitu ibu rumah tangga yang merupakan penduduk asli di lokasi penelitian. Ibu rumah tangga menjadi kunci dalam usaha kesehatan di masyarakat sebab melalui merekalah ketahanan anggota keluarga akan terwujud.

Menurut informan nyamuk Aedes banyak menggigit manusia di lingkungan luar rumah seperti lapangan berumput, semak-semak, tempat yang banyak tetumbuhan, pekarangan rumah, lingkungan sekolah dan tempat-tempat umum. Hanya sedikit informan yang menjawab bahwa nyamuk Aedes menggigit di dalam rumah, di dalam gedung sekolah dan di tempat-tempat yang dekat dengan air. Informan mengalami kesulitan untuk mencegah penularan demam berdarah karena tidak dapat memperkirakan dengan pasti kapan dan dimana pastinya terkena gigitan nyamuk Aedes.

"DB itu intinya kan digigit nyamuk, Iha masalahnya kita itu kan tidak tahu dari mana nggigitnya, dari luar rumah atau pas anak-anak itu main, kalo pas di sekolah atau dari mana kan kita juga nggak tau ... jadi kita kan tidak tahu pas waktu digigitnya itu di saat kapan dan dimana ..."

DB intinya adalah digigit nyamuk. Masalahnya kita tidak tahu dari mana menggigitnya, dari luar rumah, sewaktu anak-anak bermain, di sekolah atau dari mana juga tidak tahu. Jadi kita tidak tahu waktu dan tempat pastinya tergigit (Pujiyanti, 2011)

Berdasarkan uji hipotesi menggunakan uji chi square pada pada penelitian pada siswa SMA Negeri 1 Berastagi diketahui bahwa variabel pengetahuan tidak mempunyai hubungan yang bermakna terhadap lingkungan maka Ho diterima dengan p.value 0,177 karena pada kenyataannya siswa SMA Negeri 1 Berastagi telah memiliki cukup pengetahuan tentang pencegahan DBD karena mereke dapat menjawab pertanyaan umum mendasar tentang penyakit ini dan sebagian mereka mempunyai keluarga yang pernah menderita penyakit ini.Memang pengetahuan merupakan hasil dari tahu, dan ini terjadi setelah orang melakukan penginderaan terhadap suatu objek tertentu. Pengetahuan atau kognitif merupakan domain yang sangat yang sangat penting dalam membentuk tindakan seseorang (over behavior). Perilaku didasari oleh pengetahuan, biasanya pengetahuan seseorang diperoleh dari pengalaman yang berasal dari berbagai macam sumber (Notoatmodjo, 2007)

Pengetahuan merupakan faktor penting yang mempengaruhi sikap dan perilaku seseorang. Kurangnya 
pengetahuan dapat berpengaruh pada tindakan yang dilakukan karena pengetahuan merupakan salah satu faktor predisposisi untuk terjadinya perilaku. Oleh karena itu untuk mendidik masyarakat agar mempunyai perilaku yang baik, warga perlu diberikan pengetahuan.

Berdasarkan penelitian yang dilaksanakan pada responden pada variabel tindakan siswa tentang pencegahan DBD pada kelaurga siswa SMA Negeri 1 Berastagi maka sebagian besar tindakannya kurang dalam rangka pencegahan DBD yaitu sebanyak 193 orang $(64,3 \%)$ dan responden yang lain tindakannya baik sebanyak 107 orang $(35,7 \%)$. Perilaku manusia merupakan hasil dari segala macam pengalaman serta interaksi manusia dengan lingkungannya yang terwujud dalam pengetahuan,sikap dan tindakan. Dengan kata lain perilaku merupakan reaksi seorang individu serta stimulus yang berasal dari luar maupun dari dalam dirinya.respon ini bersifat pasif (tanpa tindakan) maupun aktif (melakukan tindakan). Hasil pada responden penelitian ini pada pertanyaan mengenai kebiasaan menggantung pakaian masih banyak yang menggantung pakaian yaitu sebanyak 267 orang (89\%). Kebiasaan menggantung pakaian dengan kejadian DBD dimana $p$-value $=0.046, \mathrm{OR}=3,9(95 \% \mathrm{CI}$ 1,108 - 9,861), yang berarti bahwa responden yang mempunyai kebiasaan menggantung pakaian mempunyai risiko 3,9 kali lebih besar daripada tidak mempunyai kebiasaan menggantung pakaian untuk terjadinya penyakit DBD di Kabupaten Semarang. Hasil yang dilakukan oleh Widyanto T (2007), yang menyatakan adanya hubungan kebiasaan menggantung pakaian dengan kejadian DBD $(\mathrm{OR}=7,851)$ pada responden di Kota Purwokerto.

Ban bekas, botol, palstik dan barang-barang lain yang dapat menampung air merupakan sarana yang memungkinkan untuk tempat perkembangbiakan nyamuk. Semakin banyak barang bekas yang dapat menampung air, semakin banyak tempat bagi nyamuk untuk bertelur dan berkembang biak, sehingga makin meningkatkan pula risiko kejadian DBD.

Berdasarkan hasil penelitian variabel perilaku pada pertanyaan mengubur barang-barang bekas maka masih banyak responden tidak mengubur barang bekas yaitu sebanyak 184 orang $(61,3 \%)$ dan hanya mengganti air di bak sebanyak 205 orang $(68,3 \%)$.

Dari hasil analisis hubungan antara variabel perilaku siswa tentang DBD mempunyai hubungan bermakna terhadap lingkungan siswa pada p.value 0,046 .

Keberadaan container sangat berperan dalam dalam keberadaan vector nyamuk Aedes, karena semakin banyak container akan semakin banyak perindukan dan akan semakin banyak populasi nyamuk Aedes maka semakin tinggi pula risiko virus DBD dengan waktu penyebaran lebih cepat sehingga jumlah kasus penyakit DBD cepat meningkat yang pada akhirnya mengakibatkan terjadinya KLB penyakit DBD. Dengan demikian program pemerintah (Ditjen PPM\&PL, 2001) berupa penyuluhan kesehatan masyarakat dalam penanggulangan penyakit DBD antara lain dengan cara menguras, menutup dan mengubur (3M) sangat tepat dan perlu dukungan luas dari masyarakat dalam pelaksanaanya. Demikian juga WHO (2000) telah menyatakan bahwa pemberantasan jentik nyamuk Aedes dengan penaburan butiran Temephos dengan dosis 1 ppm dengan efek residu selama 3 bulan cukup efektif menurunkan kepadatan populasi nyamuk Aedes atau meningkatkan angka bebas jentik, sehingga menurunkan risiko terjadinya KLB penyakit DBD.

Penyakit DBD belum ada vaksin/obatnya sehingga cara satu-satunya unutuk menghindari terjangkitnya penyakit ini dengan pencegahan. Pencegahan DBD adalah dengan mencegah gigitan nyamuk Aedes yang mengandung virus dengue terhadap manusia. Salah satu cara pencegahan penyakit DBD adalah dengan mencegah gigitan nyamuk Aedes yang mengandung virus dengue terhadap manusia.salah satu cara adalah dengan menjaga kebersihan lingkungan agar tidak menjadi media perindukan nyamuk Aedes aegypti yaitu berupa [pemberantasan sarang nyamuk (PSN), fogging, abatisasi, pelaksanaan 3M (menguras, menutup dan mengubur).dalam setiap persoalan kesehatan termasuk dalam upaya penanggulangan $\mathrm{DBD}$, faktor perilaku senantiasa berperan penting. Perhatian terhadap factor perilaku sama penting perhatian terhadap faktor lingkungan, khususnya dalam hal upaya pencegahan penyakit.

WHO juga menyarankan beberapa tindakan khusus untuk mengendalikan dan menghindarkan gigitan nyamuk. Cara terbaik untuk mengendalikan nyamuk "Aedes aegypti" adalah dengan menyingkirkan habitatnya. Masyarakat harus mengosongkan wadah air yang terbuka (sehingga nyamuk tidak dapat bertelur di dalam wadahwadah terbuka tersebut). Insektisida atau agen-agen pengendali biologi juga dapat digunakan untuk mengendalikan nyamuk di wilayah-wilayah ini.Para ilmuwan berpendapat bahwa menyemprotkan insektisida organofosfat atau piretroid tidak membantu. Air diam (tidak mengalir) harus dibuang karena air tersebut menarik nyamuk, dan juga karena manusia dapat terkena masalah kesehatan jika insektisida menggenang di dalam air diam.Untuk mencegah gigitan nyamuk, orang-orang dapat memakai pakaian yang menutup kulit mereka sepenuhnya. Mereka juga dapat menggunakan anti nyamuk (seperti semprotan nyamuk), yang membantu menjauhkan nyamuk. (DEET paling ampuh.) Orang-orang juga dapat menggunakan kelambu saat beristirahat.

\section{SIMPULAN}

Kesimpulan

1. Sebesar responden berjenis kelamin perempuan (53\%) dan berumur 15 - 17 tahun (69\%), kelas XII (56,7\%), suku Karo (70,3\%), dengan jumlah penghuni $1-5$ orang $(56 \%)$.

2. Pengetahuan siswa (p.value $=0,992)$ tidak berhubungan dengan lingkungan dalam rangka pencegahan Demam Berdarah Dengue di SMA Negeri 1 Berastagi Kecamatan Berastagi Kabupaten Karo.

3. Perilaku siswa ( $p$.value $=0,046$ berhubungan dengan lingkungan dalam rangka pencegahan Demam Berdarah Dengue di SMA Negeri 1 
Berastagi Kecamatan Berastagi Kabupaten Karo.

\section{Saran}

1. Diharapkan kepada pihak sekolah untuk dapat terus memberikan bimbingan kepada siswa tentang pencegahan DBD baik dalam bentuk penyuluhan melalui poster ataupun leaflet ataupun media lain.

2. Diharapkan kepada siswa untuk melaksanakan kegiatan kebersihan dan gotong royong disekolah guna menghindarkan adanya kasus DBD dengan melaksanakan kegiatan 3 M Plus baik di sekolah maupun dirumah.

\section{DAFTAR PUSTAKA}

Amrul Hasan, 2007. Hubungan Pemberantasan Sarang Nyamuk Demam Berdarah Dengue dan Pencegahan Gigitan Nyamuk (Aedes aegypti) Dengan Kejadian Demam Berdarah Dengue di Kota Bandar Lampung Tahun 2007. Tesis, Program Pasca Sarjana, Fakultas Kesehatan Masyarakat Universitas Indonesia.

Bhisma Murti, 1997. Prinsip dan Metode Riset Epidemiologi. Fakultas Kedokteran Universitas Indonesia.Gadjah Mada University Press, Yogyakarta.

Cendrawirda,2008, Hubungan Faktor Individu Anak, Faktor Sosiodemografi Keluarga dan Faktor Lingkungan Dengan Kejadian Demam Berdarah Dengue Pada Anak di Kota Tembilahan Kabupaten Indra Giri Hilir Provinsi Riau Tahun 2008. Tesis Program Pasca Sarjana Program Studi Epidemiologi Komunitas , Fakultas Kesehatan Masyarakat Universitas Indonesia.

Departemen Kesehatan,RI, 2001. Tata Laksana Demam Berdarah Dengue di Indonesia. Jakarta. Ditjen Pemberantasan Penyakit Menular dan Penyehatan Lingkungan Pemukiman.Hlm 1-2 2002. Pedoman Survei Entomologi DBD, Jakarta. DepKes RI , 2003. Surveilans Epidemiologi Penyakit (PLP), Panduan Praktis, Departemen Kesehatan RI, Jakarta.

2005. Pencegahan dan Pemberantasan Demam Berdarah Dengue di Indonesia.Departemen Kesehatan RI. 2009. Penyelidikan dan Penanggulangan Kejadian Luar Biasa (KLB) Penyakit Menular dan Keracunan, Departemen Kesehatan RI, Jakarta.

DinKes Provinsi Sumatera Utara, 2010. Profil Dinas Kesehatan Provinsi Sumatera Utara 2010

Green, L.W. 1980. Health Education Planning.A Diagnostic Approach Mayfield Publishing Company. USA.

Hadinegoro S, Soegijanto S, Wuryadi S, Seroso T,2001. Tatalaksana demam Berdarah Dengue di Indonesia, Jakarta. DepKes RI.
Kemenkes, 2011. Pengendalian Penyakit dan Penyehatan Lingkungan.Jakarta ; Direktorat Jenderal

Keraf,A.S Dan Dua M.2001. Ilmu Pengetahuan : Sebuah Tinjauan Filosofis. Yogyakarta ; Kanisius.

Nadezul H, 2007. Cara Mudah Mengalahkan Demam Berdarah. Jakarta. Penerbit Buku Kompas.

Notoatmodjo S, 2003. Dasar-dasar Pendidikan Kesehatan dan Perilaku.Jakarta, Rineka Cipta. 2007. Promosi Kesehatan dan Ilmu Perilaku. Rineka Cipta, Jakarta

Pujiyanti, Aryani, dkk,. 2011. Pengetahuan dan Penanggulangan Ibu Rumah tangga atas Nyamuk Demam Berdarah Dengue.

Puskesmas Kabanjahe Kabupaten Karo, 2013. Profil Puskesmas Kabanjahe Kabupaten Karo 2013, Karo : DinKes Karo.

Roose,Awida,2008. Hubungan Sosiodemografi dan Lingkungan Dengan Kejadian Demam Berdarah Dengue (DBD) di Kecamatan Bukit Raya Kota Pekan Baru tahun 2008. Tesis, Fakultas Kesehatan Masyarakat Universitas Sumatera Utara,Medan.

Ririh Y., dan Anny,V.2005. Hubungan Kondisi Lingkungan, Kaontainer dan Perilaku Masyarakat dengan Keberadaan jentik nyamuk Aedes aegypti di daerah Endemis Berdarah Dengue Surabaya; Jurnal Kesehatan Lingkungan (2) : 170-182.

Soegeng Soegijanto, 2002. Ilmu Penyakit Anak Diagnosa dan Penatalaksanaan. Jakarta, Salemba Medika.

Soegianto S, 2003. Demam Berdarah Dengue. Tinjauan dan Temuan Baru di Era 2003. Surabaya: Airlangga University Press, Surabaya.

Sri Rejeki H.Hadinegoro,dkk, 2005. Demam Berdarah Dengue.FKUI.Jakarta.

Sungkar, Saleha,. 2010. Pengaruh Penyuluhan Kesehatan Terhadap Tingkat Pengetahuan Masyarakat Dan Kepadatan Aedes aegypti Di Kecamatan Bayah, Provinsi Banten.

World Health Organization ,1998. Dengue in the WHO, Western Pasific Region. Weekly Epidemiology Record, 1998; 72:273.

.dan Dpartemen Kesehatan RI,2000. Pencegahan dan Penanggulanagan Penyakit Demam Berdarah Dengue. 2014. Dengue and Severe Dengue from World Health Organization . http://www.who.int/mediacentre/fastsheelts/fs/11 7/en/

Wibisono,B.H, 1995. Studi Epidemiologi Demam Berdarah Dengue Pada Orang Dewasa. Medika

Widiyanto,Teguh. Kajian Manajemen Lingkungan Terhadap Kejadian Demam Berdarah Dengue di Purwokerto Jawa Tengah. Tesis. Semarang. Magister Kesehatan Lingkungan.UNDIP.2007 